\title{
Marathi Language
}

National Cancer Institute

\section{Source}

National Cancer Institute. Marathi Language. NCI Thesaurus. Code C154021.

An Indo-Aryan language spoken predominantly by the Marathi people of Maharashtra, India. 